\title{
Pedology at Four Representative Sites of Southern Highland Zone of Tanzania
}

\author{
Johnson Godlove Mtama ${ }^{1, ~ *}$, Balthazar Michael Msanya ${ }^{2}$, Charles Lee Burras ${ }^{3}$ \\ ${ }^{1}$ Tanzania Agricultural Research Institute: TARI - Uyole, Mbeya, Tanzania \\ ${ }^{2}$ Department of Soil and Geological Sciences, College of Agriculture, Morogoro, Tanzania \\ ${ }^{3}$ Agronomy Department, Iowa State University, Ames, USA
}

Email address:

johnsonmtama@gmail.com (J. G. Mtama),bmmsanya@gmail.com (B. M. Msanya), 1burras@iastate.edu (C. L. Burras)

${ }^{*}$ Corresponding author

\section{To cite this article:}

Johnson Godlove Mtama, Balthazar Michael Msanya, Charles Lee Burras. Pedology at Four Representative Sites of Southern Highland Zone of Tanzania. American Journal of Agriculture and Forestry. Vol. 6, No. 5, 2018, pp. 111-121. doi: 10.11648/j.ajaf.20180605.11

Received: July 24, 2018; Accepted: August 9, 2018; Published: September 6, 2018

\begin{abstract}
To study the soils of Southern Highland Zone of Tanzania, four representative pedons of some landscapes were characterized. Their names and identifiers are Seatondale, Mbimba, Inyala, and Uyole, respectively TzSea 01, TzMb 02, TzIny 03, and TzUy04. The pedons were formed from the weathering of among other materials, colluvial igneous rocks, alluvium, eluvial soils, laterite, lacustrine sands and silts, andesite, pumice, aeolian deposits, and metamorphic rocks including coarse grained and strongly foliated biotite gneisses. Twenty soil samples were taken for laboratory characterization. In addition to classical horizon by horizon descriptions and laboratory analyses, 12 core samples were taken for soil-water retention characterization. The available water holding capacity was rated as very low to low. Pedon descriptions and particle size analysis showed clay eluviation-illuviation was the predominant pedogenic process in all pedons. Soil $\mathrm{pH}$ was rated slightly acidic to slightly alkaline. Available P ranged from $0.71 \mathrm{mg} / \mathrm{kg}$ at Mbimba to $10.67 \mathrm{mg} / \mathrm{kg}$ at Seatondale. Exchangeable bases were variable across and within the profiles; at Uyole and Inyala they were high, while at Seatondale and Mbimba they were low and medium. Values of exchangeable bases showed decreasing trends with profile depths in all sites. $\mathrm{C} / \mathrm{N}$ ratios ranged between 6 and 18, total nitrogen was rated very low to low in both $\mathrm{A}$ and $\mathrm{B}$ horizons. $\mathrm{CEC}_{\text {soil }}$ ranged between 17.2 and 36.4 $\mathrm{cmol}_{(+)} / \mathrm{kg}$. Organic carbon ranged from very low to high. The soils apparently developed from extreme and moderate weathering of parent materials. According to the USDA Soil Taxonomy, the pedons classified as Fine, Illitic, Active, Isothermic Typic Hapludult; Fine, Illitic, Active, Isothermic Andic Paleudalf; Fine, Illitic, Active, Isothermic, Mollic Paleudalf; Pumiceous, Mixed, Superactive, Isothermic, Typic Hapludand for Seatondale, Mbimba, Inyala, and Uyole, respectively. The soil depths were deep and very deep. Moisture stress and low levels of some macro-elements highly limited the productivity of the soils.
\end{abstract}

Keywords: Pedology, USDA Soil Taxonomy, Pedons, Southern Highlands, Tanzania

\section{Introduction}

The soils, landscapes and landforms of Tanzania are diverse. The major terrain features include Mounts Kilimanjaro, Ngorongoro, Rungwe, Meru active and dormant volcanoes, the Great Rift Valley, Udzungwa, Kipengere and Livingstone mountain ranges of varying origins such as tectonic blocks and fold systems, coastal plains, interior plains, tectonic lakes with associated lake plains and terraces. Also important are the major rivers including the Great
Ruaha, Rufiji, Ruvu, Pangani and Malagalasi rivers, all of which with sizeable floodplains, terraces and delta systems. Each of these features is geomorphically active, resulting in a wide range of local terrain features including alluvial fans, abandoned oxbows, sand dunes, landslide scars and rotational slumps, etc. As a result, the pedological perspective of Tanzania is one of tremendous regional and local parent material variation including alluvium and colluvium, volcanic ash, aeolian sands as well as seemingly every type of rock known to geology [1]. 
There is a great precipitation variation across Tanzania, in large part caused by the mountain ranges and elevation variation [1]. In general the precipitation increases with increase in elevation across the country, the highlands receiving mean annual rainfall ranging from 100 to $2300 \mathrm{~mm}$. The central and coastal parts receive rainfall between 800 and $1200 \mathrm{~mm}$. The mean annual temperature differs with location, relief and elevation. It ranges between $27^{\circ} \mathrm{C}$ and $29^{\circ} \mathrm{C}$ in coastal regions and offshore, $20^{\circ} \mathrm{C}$ and $30^{\circ} \mathrm{C}$ in central, northern and western parts, less than $15^{\circ} \mathrm{C}$ for the highlands [2].

Biota also varies with elevation. The highlands are dominated by savannah and tropical forest in altitude $>1500$ $\mathrm{m}$ asl. The transition to lowlands is characterized by Baobab trees, grassland, Mangrove forests, etc. [2]. Based on precipitation patterns, altitude, average water holding capacity and growing seasons, soils and landscapes, Tanzania is divided into 7 agro-ecological zones. Southern Highland Zone belongs to AEZ 5, which extends from Morogoro to Lake Nyasa covering Iringa and Mbeya regions in the South; Ufipa plateau of Sumbawanga in the southwest and along shore of Lake Tanganyika in Kigoma in the west. The landscapes range from undulating plains to dissected hills and mountains in the South. There is Rift valley in the southwest and swampy valleys in the west [2].

Soil survey reports identify Ferric, Chromic and Eurtric Cambisols (39.7\%), Rhodic and Haplic Ferralsols (13.4\%), and Humic Ferric Acrisols (9.6\%) as some of the predominant soils across the country [3]. The corresponding USDA Soil Taxonomy taxa are Inceptisols, Oxisols, and Ultisols, respectively. Many soils in Tanzania are highly weathered and their capacity to hold and release plant available nutrients is compromised [3, 4]. However, the volcanic soils in parts of the Southern Highland Zone of Tanzania are rich in soil organic matter (SOM), P and K, which implies higher fertility potentials [1]. Different geological ages account for the development of these different types of soils across the country.

The objective of this paper was to characterize and classify four pedons that represent important maize producing soils of the Southern Highland Zone of Tanzania.

\section{Materials and Methods}

\subsection{Study Area}

This study was conducted across three specific administrative units (Mbozi and Mbeya districts, and Iringa Municipality) of SHZT. Field sites were located at Mbimba, Uyole, Inyala and Seatondale, respectively (Figure 1 and Table 1). Site information such as weather, elevation, parent materials, landforms, land use, soil temperature and moisture regimes, geographical location coordinates were determined using topographic and geological maps and Garmin etrex 10 GPS following standard field description guidebooks [5-8].

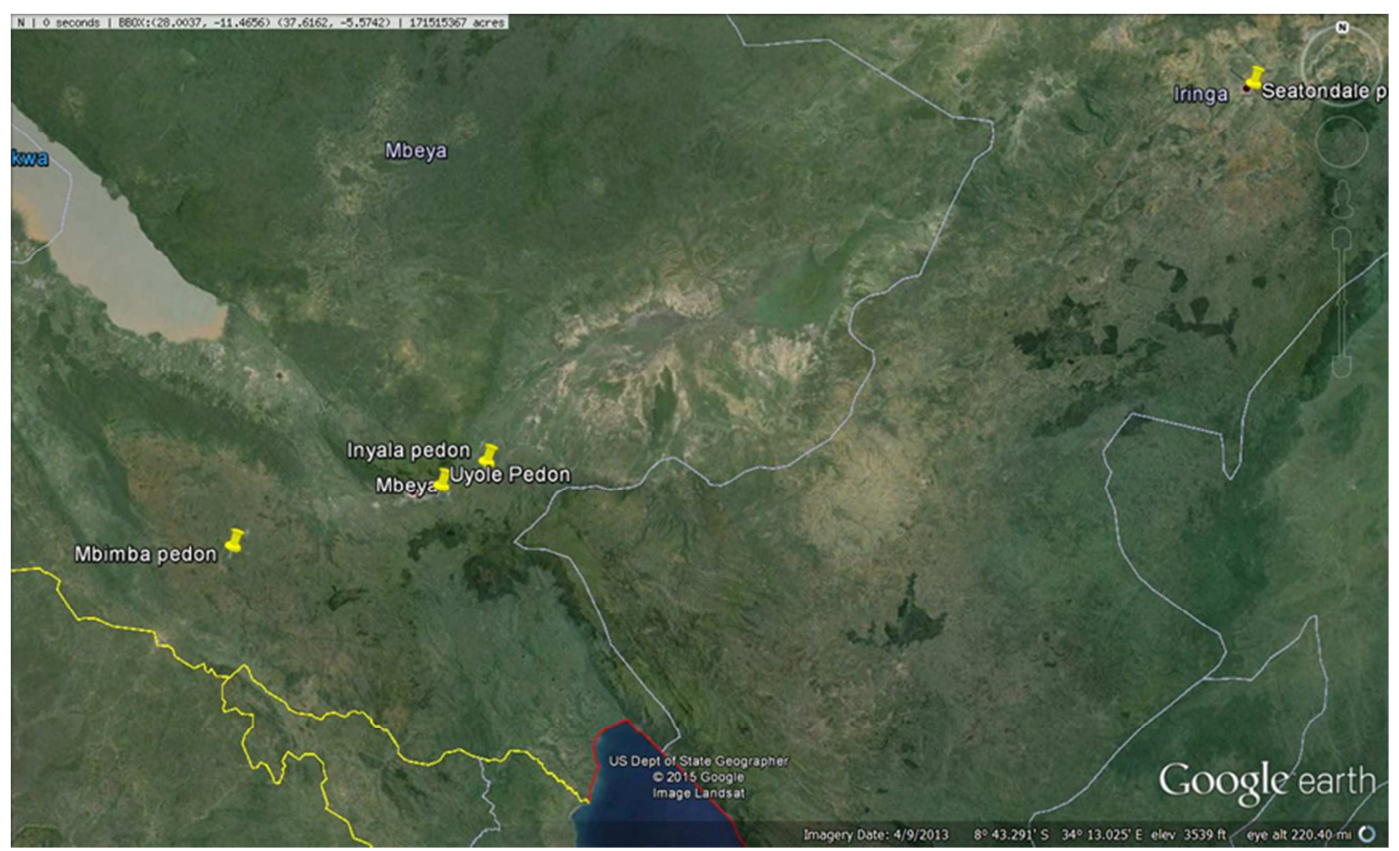

Figure 1. Location of the pedons in the SHZT. Image from Google earth.

Table 1. Locations, elevation, landform, and land use characterization of the four representative pedons at the SHZT.

\begin{tabular}{|c|c|c|c|c|c|c|c|c|}
\hline Pedon Id & Pedon code & District & Coordinates & Altitude (m.a.s.l) & Landform & Land use & SMR & STR \\
\hline Uyole & Uy01 & Mbeya Rural & $033^{\circ} 30.98^{\prime} \mathrm{E} 08^{\circ} 55.04^{\prime} \mathrm{S}$ & 1779 & Alluvial fan & Cultivation & Udic & Isothermic \\
\hline Inyala & Iny02 & Mbeya Rural & $033^{\circ} 38.20^{\prime} \mathrm{E} 08^{\circ} 51.1^{\prime} \mathrm{S}$ & 1515 & Flat plain & Cultivation & Udic & Isothermic \\
\hline Mbimba & Mbi03 & Mbozi & $032^{\circ} 57.29^{\prime} \mathrm{E}, 09^{\circ} 05.31^{\prime} \mathrm{S}$ & 1596 & Inclined plain & Cultivation & Udic & Isothermic \\
\hline Seatondale & Sea 04 & Iringa Municipal & $035^{\circ} 41.873^{\prime} \mathrm{E} 07^{\circ} 47.502^{\prime} \mathrm{S}$ & 1537 & Backslope & Cultivation & Udic & Isothermic \\
\hline
\end{tabular}

STR: soil temperature regime, SMR: soil moisture regime 


\subsection{Field Work}

The study sites were located on farms belonging to Uyole Agricultural Research Institute. The institute originally selected the research farms because they have representative soils and landscapes of the Southern Highland Zone agroecology. Three criteria were used to select locations of the pedons: review of the landscapes from Google earth, discussion between the farm manager, zonal maize breeder and the senior author, and lastly execution of soil reconnaissance. Each site was pedologically surveyed by auguring along transects. Working soil map units were established to provide the general view of soil distribution at each site using the principles in the USDA Soil Survey Manual [8]. Following site characterization, one representative pedon was opened at each site for detailed description and characterization [7]. Twenty characterization samples (one sample from each horizon) were collected from the four pedons. Twelve samples ( 3 for each pedon) were collected for soil water and bulk density characterization. Depths of collections were $0-5 \mathrm{~cm}, 45-50 \mathrm{~cm}$ and $95-100$ $\mathrm{cm}$.

\subsection{Laboratory Methods}

Following drying and grinding to pass through a 2-mm sieve, the 20 horizon samples were analyzed at the Sokoine University, Soil Science Laboratory for texture, $\mathrm{pH}$, $\mathrm{EC}, \% \mathrm{SOC}, \% \mathrm{~N}$, available $\mathrm{P}$, exchangeable bases determination, $\mathrm{Fe}, \mathrm{Cu}, \mathrm{Mn}$, and $\mathrm{Zn}$. The 12 undisturbed core samples were analyzed at Mlingano Agricultural Research Institute for bulk density and moisture retention characteristics. Bulk density was determined by the core method [9]. Soil moisture retention characteristics were studied using sand kaolin box for low pressure values and pressure apparatus for high pressure values [10]. Particle size analysis was determined by the hydrometer method after dispersion with sodium hexametaphosphate 5\% [10]. Textural classes were determined using the USDA textural triangle [7].

Soil $\mathrm{pH}$ was measured in water and $1 \mathrm{M} \mathrm{KCl}$ at a ratio of 1:2.5 soil-water and soil- $\mathrm{KCl},[11]$ and at a ratio of 1:50 soil$1 \mathrm{MNaF}$, with measurements taken after 2 minutes $[10,12]$. Organic carbon was determined by the Walkley and Black wet oxidation method [13]. Organic carbon values obtained were converted to organic matter by multiplying by a factor of 1.724 [14]. Total $\mathrm{N}$ was determined using micro-Kjeldahl digestion-distillation method as described by [15]. Available phosphorus was determined using fitrates extracted by the Bray and Kurtz-1 method [16] and determined by spectrophotometer at $884 \mathrm{~nm}$ following color developed by the Molybdenum blue method [17, 18]. Cation exchange capacity of the soil $\left(\mathrm{CEC}_{\text {soil }}\right)$ and exchangeable bases were determined by saturating soil with neutral $1 \mathrm{M} \mathrm{NH}_{4} \mathrm{OAc}$ (ammonium acetate) and the adsorbed ammonium ions $\left(\mathrm{NH}_{4}{ }^{+}\right)$were displaced by using $1 \mathrm{M} \mathrm{KCl}$ and then determined by Kjeldahl distillation method for estimation of CEC of the soil [19]. The exchangeable bases $\left(\mathrm{Ca}^{2+}, \mathrm{Mg}^{2+}\right.$, $\mathrm{Na}^{+}$and $\mathrm{K}^{+}$) were determined by atomic absorption spectrophotometer [20]. The total exchangeable bases (TEB) were calculated arithmetically as the sum of the four exchangeable bases $\left(\mathrm{Ca}^{2+}, \mathrm{Mg}^{2+}, \mathrm{Na}^{+}\right.$and $\left.\mathrm{K}^{+}\right)$for a given soil sample and the base saturation percentage calculated by dividing TEB by the sample respective CEC multiplied by 100. Micronutrients $\mathrm{Fe}, \mathrm{Cu}, \mathrm{Mn}$ and $\mathrm{Zn}$ were determined by DTPA method. The determination by atomic adsorption spectrophotometer was done using standard atomic adsorption procedures $[3,21]$. The electrical conductivity was determined in 1:2.5 soils:water suspensions using an electrical conductivity meter [22].

\section{Results and Discussion}

\subsection{Morphology of the Studied Pedons}

The four pedons have depths ranging from deep to very deep and have well-developed diagnostic horizons (Figure 2 and Table 3). The epipedons are generally dark colored while the $\mathrm{B}$ horizons are brown to red, which indicates generally well drained conditions. However, redoxmorphic features have also been observed in B horizons of Inyala and Mbimba. This indicate periodic shallow water table in these sites. The soils the study areas have weak fine to strong coarse subangular blocky structures. In almost all pedons except Inyala the soils showed the consistence of hard to firm when dry and friable to very friable when moist, and the wet consistence of none sticky to none plastic, slightly stick to plastic. The horizon boundaries were quite distinct ranging from abrupt to clear with smooth or wavy horizon topography. This is in line with what other workers found in their study on characterization of volcanic ash soils in SouthWertern Tanzania; Morphology, physico-chemical properties and classification $[23,24]$.

Table 2. Parent material, weather condition, surface and slope characteristics and vegetation of the four representative pedons of the SHZ.

\begin{tabular}{|c|c|c|c|c|c|c|c|}
\hline Pedon Id & District & $\begin{array}{l}\text { Parent } \\
\text { rock/material }\end{array}$ & $\begin{array}{l}\text { Weather } \\
\text { condition }\end{array}$ & Site characteristics & Surface characteristics & $\begin{array}{l}\text { Native } \\
\text { vegetation }\end{array}$ & $\begin{array}{l}\text { Farming } \\
\text { system }\end{array}$ \\
\hline Uyole & $\begin{array}{l}\text { Mbeya } \\
\text { Rural }\end{array}$ & $\begin{array}{l}\text { Rungwe } \\
\text { Volcanic ash } \\
\text { (Tuffs to } \\
\text { phonolitics and } \\
\text { younger basalts) }\end{array}$ & $\begin{array}{l}\text { Sunny, no } \\
\text { rain for past } \\
6 \text { months }\end{array}$ & $\begin{array}{l}\text { Slope: }<2 \% \\
\text { Slope type: straight } \\
\text { Slope length: }>300 \mathrm{~m} \\
\text { Position: Toe slope }\end{array}$ & $\begin{array}{l}\text { Sealing: Yes } \\
\text { Thickness: } 25 \mathrm{~cm} \\
\text { Drainage class: well drained } \\
\text { Erosion: None } \\
\text { Infiltration: yes }\end{array}$ & Savannah & $\begin{array}{l}\text { Corn - } \\
\text { corn } \\
\text { rotation }\end{array}$ \\
\hline Mbimba & Mbozi & $\begin{array}{l}\text { Neogene (mbuga } \\
\text { and alluvium, } \\
\text { brown eluvial }\end{array}$ & $\begin{array}{l}\text { Sunny, } \\
\text { partly } \\
\text { cloudy, no }\end{array}$ & $\begin{array}{l}\text { Slope: } 3 \% \\
\text { Slope type: straight } \\
\text { Slope length: }>400 \mathrm{~m}\end{array}$ & $\begin{array}{l}\text { Sealing: yes } \\
\text { Thickness: } 15 \mathrm{~cm} \\
\text { Craking: very little }\end{array}$ & $\begin{array}{l}\text { Woodland } \\
\text { and grassland }\end{array}$ & $\begin{array}{l}\text { Corn - } \\
\text { soybean } \\
\text { rotation }\end{array}$ \\
\hline
\end{tabular}




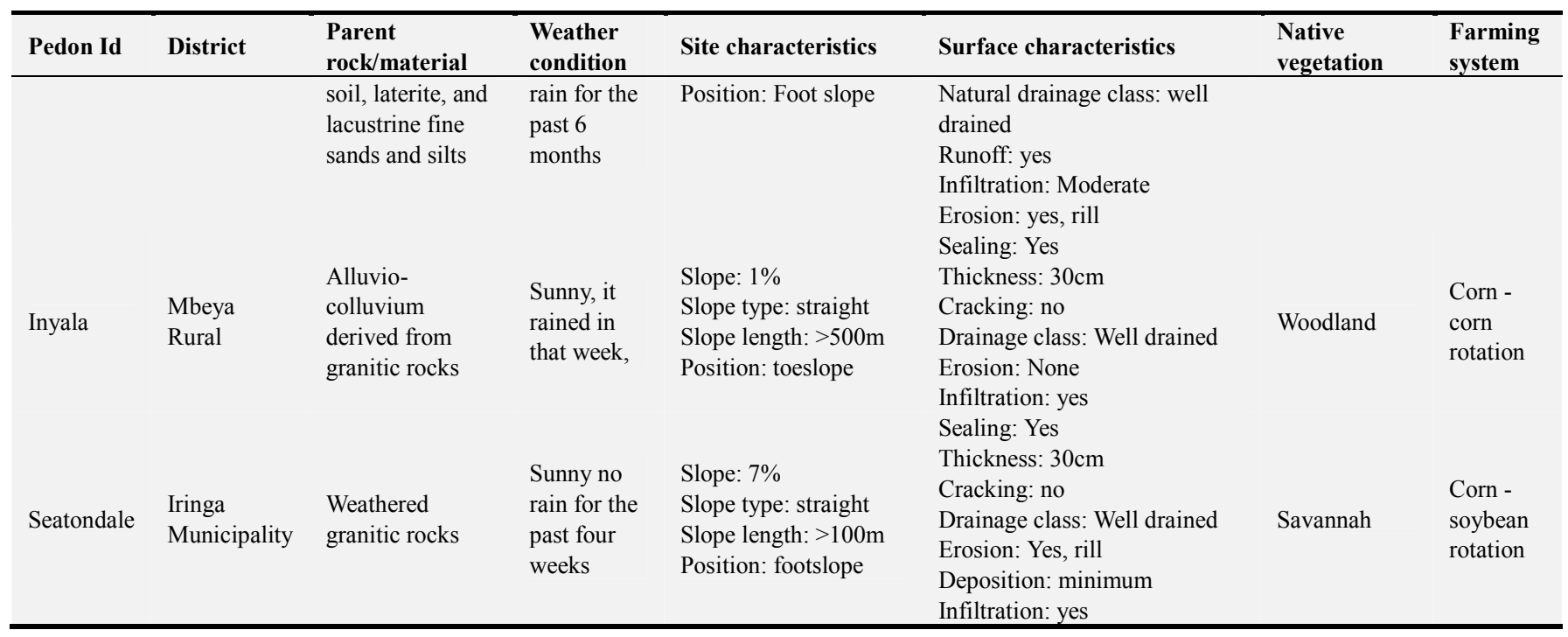
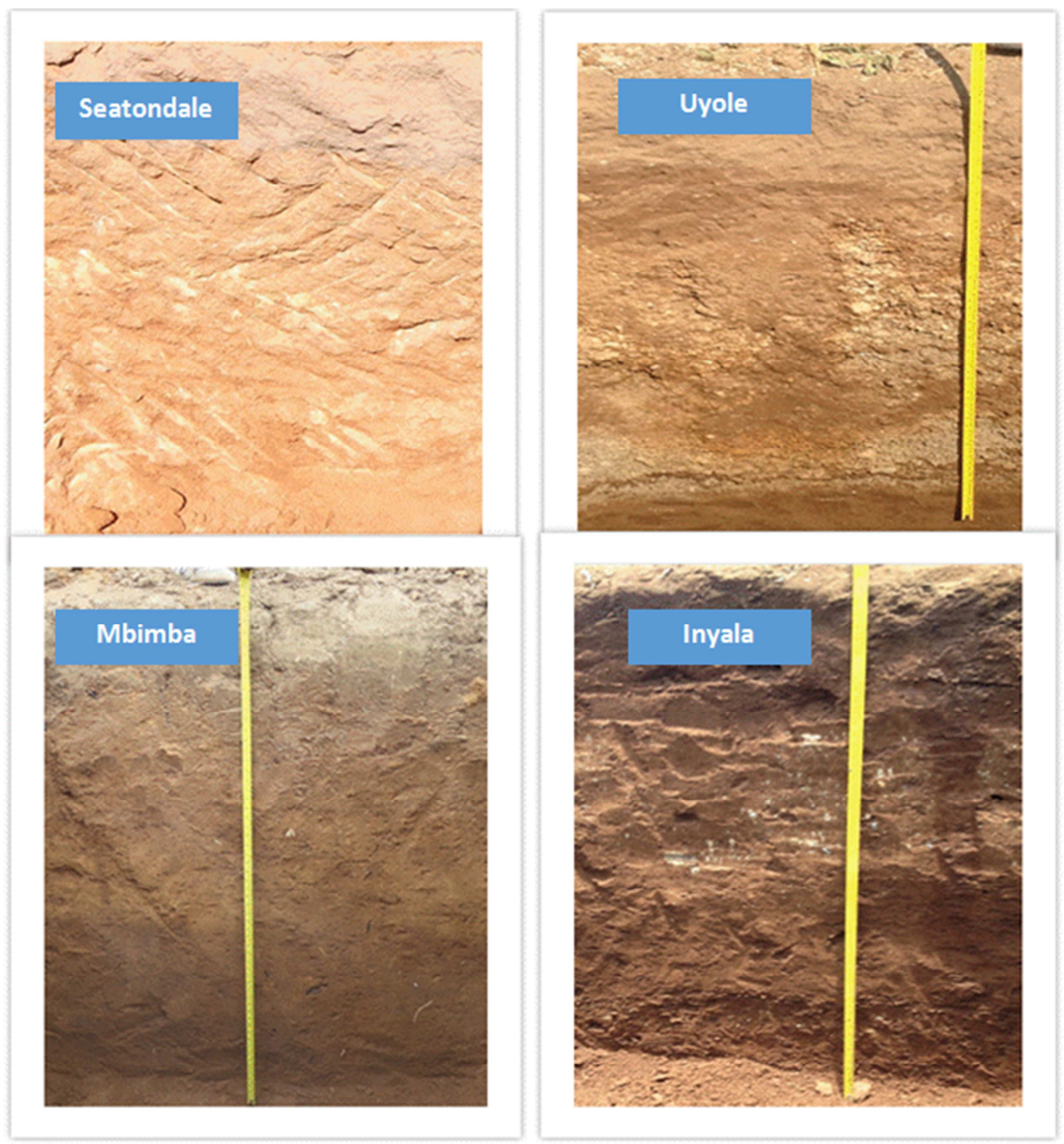

Figure 2. Photograms of representative pedons of the SHZT. 
Table 3. Textural class, color, consistence, structure and horizon boundary properties of representative pedons of SHZT

\begin{tabular}{|c|c|c|c|c|c|c|c|c|}
\hline Profile Id & Horizon & Depth (cm) & Texture & Dry color & Moist color & Consistence & Structure & Horizon boundary \\
\hline \multirow{6}{*}{ Seatondale } & Ap & $0-12$ & $\mathrm{~S}$ & 10YR5/1 & 10YR3/3 & fr,vfr & sbk & as \\
\hline & $\mathrm{AB}$ & $12-19$ & LS & 10YR4/1 & 10YR3/4 & $\mathrm{fr}, \mathrm{vfr}$ & sbk & as \\
\hline & $\mathrm{Bt} 1$ & $19-30$ & SCL & $5 \mathrm{YR} 4 / 2$ & $5 Y R 3 / 4$ & vh,vfi & sbk & $\mathrm{cw}$ \\
\hline & $\mathrm{Bt} 2$ & $30-54$ & $\mathrm{SC}$ & 7.5YR4/6 & $5 \mathrm{YR} 4 / 6$ & vh,vfi & sbk & gw \\
\hline & $\mathrm{Bt} 3$ & $54-84$ & SCL & 7.5YR4/6 & $7.5 \mathrm{YR} 4 / 6$ & vh,vfi & sbk & gw \\
\hline & $\mathrm{Bt} 4$ & $84+$ & $\mathrm{SC}$ & 7.5YR4/6 & $7.5 \mathrm{YR} 4 / 6$ & vh,vfi & sbk & - \\
\hline \multirow[t]{5}{*}{ Mbimba } & Ap & $0-12$ & $\mathrm{C}$ & 10YR4/3 & 10YR3/1 & $h, f r$ & sbk & as \\
\hline & $\mathrm{BA}$ & $12-50$ & $\mathrm{C}$ & $7.5 \mathrm{YR} 3 / 3$ & $10 \mathrm{YR} 4 / 4$ & $h, f r$ & sbk & cs \\
\hline & $\mathrm{Bt} 1$ & $50-84$ & $\mathrm{C}$ & 7.5YR4/6 & 10YR3/4 & $h, f r$ & sbk & cs \\
\hline & $\mathrm{Bt} 2$ & $84-117$ & $\mathrm{C}$ & 7.5YR4/4 & 10YR4/4 & $h, f r$ & sbk & cs \\
\hline & $\mathrm{Bt} 3$ & $117+$ & $\mathrm{C}$ & $7.5 \mathrm{YR} 3 / 3$ & $7.5 \mathrm{YR} 3 / 4$ & $h, f r$ & sbk & - \\
\hline \multirow[t]{5}{*}{ Inyala } & Ap & $0-12$ & SCL & 7.5YR4/3 & $7.5 \mathrm{YR} 3 / 3$ & $h, f r$ & sbk & as \\
\hline & $\mathrm{BA}$ & $12-47$ & $\mathrm{C}$ & 7.5YR4/4 & $7.5 \mathrm{YR} 3 / 4$ & $\mathrm{~h}, \mathrm{fi}$ & sbk & cs \\
\hline & Bt1 & $47-78$ & $\mathrm{C}$ & $7.5 \mathrm{YR} 5 / 4$ & $7.5 \mathrm{YR} 3 / 6$ & $h, f i$ & sbk & cs \\
\hline & $\mathrm{Bt} 2$ & $78-120$ & $\mathrm{C}$ & 7.5YR5/4 & $7.5 \mathrm{YR} 3 / 3$ & $h, f i$ & sbk & cs \\
\hline & $\mathrm{Bt} 3$ & $120+$ & $\mathrm{C}$ & 7.5 YR4/6 & 7.5YR4/6 & $h, f i$ & sbk & - \\
\hline \multirow[t]{4}{*}{ Uyole } & Ap & $0-20$ & SCL & $7.5 \mathrm{YR} 4 / 3$ & $7.5 \mathrm{YR} 3 / 1$ & h,vfr & sbk & as \\
\hline & $\mathrm{BA}$ & $20-30$ & SCL & 7.5YR3/4 & $7.5 \mathrm{YR} 3 / 2$ & h,vfr & sbk & gi \\
\hline & $\mathrm{CB}$ & $30-130$ & SCL & 7.5YR8/1 & 7.5YR8/1 & 1 & - & gs \\
\hline & $2 \mathrm{Bt}$ & $130+$ & SCL & $7.5 \mathrm{YR} 3 / 3$ & $7.5 \mathrm{YR} 4 / 3$ & h,vfr & sbk & - \\
\hline
\end{tabular}

$\mathrm{C}=$ clay; $\mathrm{S}=$ sand; $\mathrm{LS}=$ loamy sand; $\mathrm{SC}=$ sandy clay; fr = friable; vfr= very friable; vh=very hard; $\mathrm{h}=$ hard; vfi=very firm; l=loose; sbk =sub angular blocky; as = abrupt smooth; $\mathrm{c}=$ clear; $\mathrm{gi}=$ gradual irregular; $\mathrm{gs}=$ gradual smooth; $\mathrm{w}=$ wavy; $\mathrm{gw}=$ gradual wavy; $\mathrm{aw}=$ abrupt wavy; $\mathrm{cw}=\mathrm{clear}$ wavy

Table 4. Bulk density and available water holding capacity of four pedons from the SHZT.

\begin{tabular}{|c|c|c|c|c|c|}
\hline \multirow{2}{*}{ Pedon Id } & \multirow{2}{*}{ Horizon } & \multirow{2}{*}{ Depth (cm) } & \multirow{2}{*}{$\begin{array}{l}\text { Bulk density } \\
\left(\mathrm{g} / \mathrm{cm}^{3}\right)\end{array}$} & \multicolumn{2}{|c|}{ Available water capacity } \\
\hline & & & & $\%$ vol/vol & $\mathbf{m m} / \mathbf{m}$ \\
\hline \multirow[t]{6}{*}{ Seatondale } & Ap & $0-12$ & 1.34 & 4.0 & 40 \\
\hline & $\mathrm{AB}$ & $12-19$ & nd & $\mathrm{Nd}$ & nd \\
\hline & Bt1 & $19-30$ & nd & $\mathrm{Nd}$ & nd \\
\hline & $\mathrm{Bt} 2$ & $30-54$ & 1.48 & 3.1 & 31 \\
\hline & $\mathrm{Bt} 3$ & $54-84$ & nd & $\mathrm{Nd}$ & nd \\
\hline & Bt4 & $84+$ & 1.58 & 2.9 & 29 \\
\hline \multirow[t]{5}{*}{ Mbimba } & Ap & $0-12$ & 1.15 & 6.6 & 66 \\
\hline & $\mathrm{BA}$ & $12-50$ & 0.88 & 5.0 & 50 \\
\hline & Bt1 & $50-84$ & nd & $\mathrm{Nd}$ & nd \\
\hline & $\mathrm{Bt} 2$ & $84-117$ & 0.79 & 5.2 & 52 \\
\hline & $\mathrm{Bt} 3$ & $117+$ & nd & $\mathrm{Nd}$ & nd \\
\hline \multirow[t]{5}{*}{ Inyala } & Ap & $0-12$ & 1.46 & 4.0 & 40 \\
\hline & BA & $12-47$ & 1.51 & $\mathrm{Nd}$ & nd \\
\hline & Bt1 & $47-78$ & nd & 4.0 & 40 \\
\hline & $\mathrm{Bt} 2$ & $78-120$ & 1.43 & 4.3 & 43 \\
\hline & $\mathrm{Bt} 3$ & $120+$ & nd & $\mathrm{Nd}$ & nd \\
\hline \multirow[t]{4}{*}{ Uyole } & $\mathrm{Ap}$ & $0-20$ & 0.99 & 5.0 & 50 \\
\hline & $\mathrm{BA}$ & $20-30$ & nd & $\mathrm{Nd}$ & nd \\
\hline & $\mathrm{CB}$ & $30-130$ & 0.80 & 7.0 & 70 \\
\hline & $2 \mathrm{Bt}$ & $130+$ & 0.79 & $\mathrm{Nd}$ & nd \\
\hline
\end{tabular}

nd $=$ not determined

Table 5. Particle size distribution of the representative pedons of SHZT.

\begin{tabular}{llllll}
\hline Pedon Id & Horizon & Depth $(\mathbf{c m})$ & \% clay & \% silt & \% sand \\
\hline Seatondale & Ap & $0-12$ & 7.8 & 3.3 & 88.9 \\
& AB & $12-19$ & 9.8 & 3.3 & 86.9 \\
& Bt1 & $19-30$ & 39.8 & 1.3 & 58.9 \\
& Bt2 & $30-54$ & 33.8 & 5.3 & 60.9 \\
& Bt3 & $54-84$ & 35.8 & 3.3 & 60.9 \\
& Bt4 & $84+$ & 29.8 & 1.3 & 68.9 \\
\hline
\end{tabular}




\begin{tabular}{llllll}
\hline Pedon Id & Horizon & Depth $(\mathbf{c m})$ & \% clay & \% silt & \% sand \\
\hline Mbimba & Ap & $0-12$ & 41.8 & 17.3 & 40.9 \\
& BA & $12-50$ & 55.8 & 13.3 & 30.9 \\
& Bt1 & $50-84$ & 41.8 & 17.3 & 40.9 \\
& Bt2 & $84-117$ & 51.8 & 13.3 & 34.9 \\
Inyala & Bt3 & $117+$ & 53.8 & 13.3 & 32.9 \\
& Ap & $0-12$ & 29.8 & 17.3 & 52.9 \\
& BA & $12-47$ & 43.8 & 15.3 & 40.9 \\
Uyole & Bt1 & $47-78$ & 45.8 & 17.3 & 36.9 \\
& Bt2 & $78-120$ & 41.8 & 19.3 & 38.9 \\
& Bt3 & $120+$ & 55.8 & 13.3 & 30.9 \\
& Ap & $0-20$ & 25.8 & 23.3 & 50.9 \\
& BA & $20-30$ & 33.8 & 17.3 & 48.9 \\
\hline
\end{tabular}

\subsection{Physical and Chemical Properties of the Studied Pedons}

\subsubsection{Bulk Density}

The bulk density ranged between 1.46 to $0.99 \mathrm{~g} / \mathrm{cm}^{3}$ for the A horizons and 1.58 to $0.79 \mathrm{~g} / \mathrm{cm}^{3}$ for the $\mathrm{B}$ horizons in the study pedons (Table 4). Soil bulk density increased down the profile at Seatondale, and decreased down the profile at Mbimba and Uyole. At Seatondale, the B horizons were observed to have higher bulk densities compared to A horizons. High bulk densities $>1.75 \mathrm{~g} / \mathrm{cm}^{3}$ for sand or 1.46 to $1.63 \mathrm{~g} / \mathrm{cm}^{3}$ for silt and clay may impose many stresses such as mechanical resistance, poor aeration and changes in hydrological systems in soils [23]. However for this study, the bulk density values indicate that the soils are not compacted. Thus, air and vertical water movements are potentially not limited because of optimal porosity [23]. The low bulk densities in the A horizons indicate the presence of high organic matter content which translates to ability of these soils to retain moisture and nutrients, quality that indicates a good potential of such soils for agricultural interventions. The vice versa is true.

\subsubsection{Particle size Distribution and Textural Class}

Soil texture is the most stable physical characteristic which influences other physical and chemical properties of the soils like moisture retention, root penetration and nutrient retentions. Clayey texture was observed to be predominant in the Mbimba and Inyala pedons. The sandy clay loam texture is predominant in the A horizons of Uyole and Inyala and some B horizons of Seatondale. The B horizons of Seatondale are characterized by loamy sand and sandy clay textures (Table 5). Generally, sand content decreases down the profile almost in all pedons, while the clay content is generally higher in B horizons than in A horizons (Table 5), which is an indicator of eluviation-illuviation pedogenic processes. The results of this property indicate that the soils of the study areas are good for agricultural production.

\subsubsection{Available Water Holding Capacity and Water Retention Characteristics}

Soil water holding capacity ranged between 4 and 7\% (Table 4). It increases with depth for Inyala and decreased for Uyole, Seatondale and Mbimba. This could possibly be attributed to the amount of organic matter in the A horizons. The A horizons in Inyala and Uyole have lower water holding capacities compared to B horizons (Table 4). Both, the $\mathrm{A}$ and $\mathrm{B}$ horizons, showed very low to low available water holding capacities, while the B horizons had extremely low values of AWHC at Seatondale and very low to low at Mbimba, Uyole and Inyala sites [24]. Specifically, water retention characteristics (Figure 3) varied across and within the pedons. For Inyala, the A horizons were observed to have low water retention characteristics compared to B horizons at low pressure, whereas at high pressure all the soils were observed to have nearly the same water retention characteristics. At Seatondale, the observation was A horizons less than B horizons. For Mbimba, the A horizon was nearly the same as B horizon at lower pressure. The B horizon was observed to have high water retention characteristics at low pressure. The observation at high pressure was the A horizons less than the B horizons. For Uyole, the trend was B horizons less than A horizons at lower pressure whereas at higher pressure the trend was the $\mathrm{B}$ horizons greater than the A horizons. This variability can be explained by differences in clay mineralogy and the associated soil structure of the respective soils [25]. Generally, the water retention values for the A horizons of the study sites showed higher values at Uyole followed by Mbimba, Inyala and Seatondale. However, for the B horizons, highest water retention values were observed at Mbimba and Uyole and lowest at Seatondale. From these results, water retention characteristics are a limiting factor for corn production of the representative soils of the SHZT especially during dry periods [26]. 


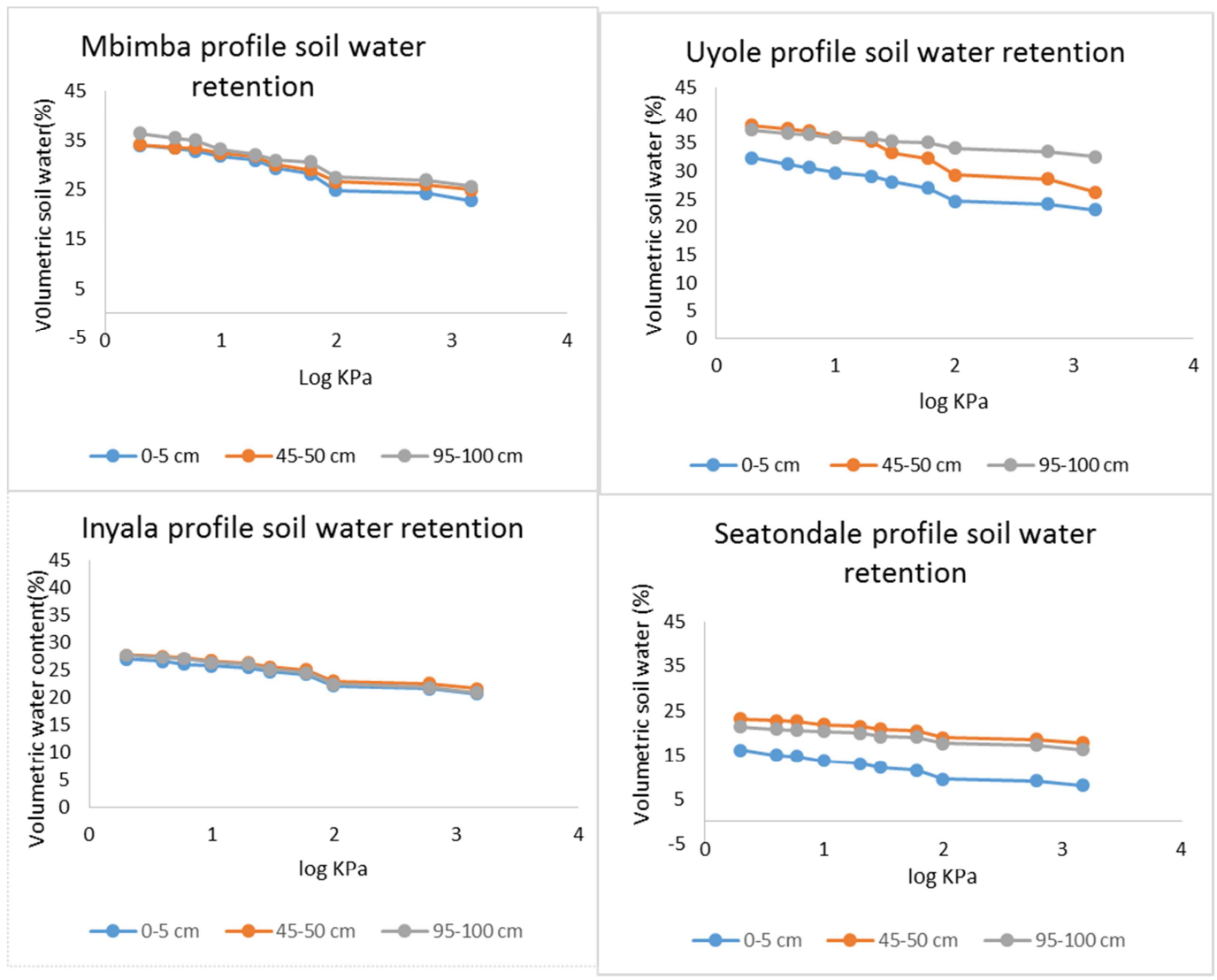

Figure 3. Water retention characteristics of the representative pedons of the SHZT.

\subsubsection{Soil pH}

The soils of Seatondale are slightly acidic in the A horizons and $\mathrm{B}$ horizons except for the $\mathrm{AB}$ horizon. The pedon's reaction ranged between medium and slightly acid. The soil's $\mathrm{pH}$ values show a constant trend across the profile. The soils of Inyala have medium to slight acidity for both A and $\mathrm{B}$ horizons. In Uyole pedon the predominant $\mathrm{pH}$ values range between slight acidity for A horizons and mild alkalinity for B horizons [24]. The A horizons are slightly acidic and $\mathrm{B}$ horizons mildly alkaline. The $\mathrm{pH}$ values show a general trend of increasing down the profile specifically for Uyole site (Table 6). The soils indicate effective potential acidity with the $\mathrm{pH}$ buffer capacity ranging between 0.96 and 2.48 units [27].

Table 6. Soil pH, EC, organic carbon and nitrogen content and available P in four representative pedons of the SHZT.

\begin{tabular}{|c|c|c|c|c|c|c|c|c|c|c|}
\hline \multirow[t]{3}{*}{ Pedon Id } & \multirow[t]{3}{*}{ Horizon } & \multirow{3}{*}{$\begin{array}{l}\mathrm{pH} \\
\mathrm{H}_{2} \mathrm{O}\end{array}$} & \multirow[b]{3}{*}{$\mathrm{KCl}$} & \multirow[b]{3}{*}{$\mathrm{NaF}$} & \multirow{3}{*}{$\begin{array}{l}\mathrm{EC} \\
(\mathrm{mS} / \mathrm{cm})\end{array}$} & \multirow[t]{2}{*}{$\% \mathrm{OC}$} & \multirow[t]{2}{*}{$\%$ OM } & \multirow[t]{2}{*}{$\% \mathrm{~N}$} & \multirow{2}{*}{$\begin{array}{l}\text { C/N } \\
\text { Ratio }\end{array}$} & \multirow{2}{*}{$\begin{array}{l}\text { Avail. P } \\
\text { (Bray 1) }\end{array}$} \\
\hline & & & & & & & & & & \\
\hline & & & & & & & & & & mg P/kg \\
\hline \multirow[t]{6}{*}{ Seatondale } & $\mathrm{Ap}$ & 6.16 & 4.75 & 8.20 & 1.38 & 0.65 & 1.12 & 0.05 & 13 & 10.67 \\
\hline & $\mathrm{AB}$ & 5.98 & 4.64 & 8.13 & 0.06 & 0.40 & 0.70 & 0.05 & 8 & 10.42 \\
\hline & Bt1 & 6.15 & 4.54 & 7.87 & 0.05 & 0.41 & 0.71 & 0.04 & 10 & 2.42 \\
\hline & $\mathrm{Bt} 2$ & 6.24 & 4.92 & 7.75 & 0.04 & 0.25 & 0.43 & 0.02 & 12 & 1.92 \\
\hline & $\mathrm{Bt} 3$ & 6.21 & 4.86 & 7.66 & 0.04 & 0.28 & 0.49 & 0.05 & 6 & 1.83 \\
\hline & $\mathrm{Bt} 4$ & 6.16 & 5.16 & 7.43 & 0.18 & 0.99 & 1.72 & 0.06 & 17 & 2.87 \\
\hline \multirow[t]{5}{*}{ Mbimba } & Ap & 5.50 & 4.08 & 8.50 & 0.10 & 0.84 & 1.45 & 0.07 & 13 & 5.17 \\
\hline & $\mathrm{BA}$ & 5.88 & 4.38 & 8.89 & 0.04 & 0.90 & 1.56 & 0.05 & 18 & 1.04 \\
\hline & $\mathrm{Bt} 1$ & 6.34 & 4.74 & 9.38 & 0.03 & 0.35 & 0.62 & 0.03 & 13 & 0.71 \\
\hline & $\mathrm{Bt} 2$ & 6.20 & 4.72 & 9.10 & 0.04 & 0.35 & 0.61 & 0.04 & 10 & 0.92 \\
\hline & $\mathrm{Bt} 3$ & 6.40 & 4.66 & 8.80 & 0.04 & 0.44 & 0.77 & 0.04 & 10 & 1.04 \\
\hline \multirow[t]{5}{*}{ Inyala } & Ap & 6.00 & 4.60 & 8.24 & 0.12 & 1.07 & 1.86 & 0.09 & 13 & 12.50 \\
\hline & $\mathrm{BA}$ & 5.92 & 4.38 & 7.96 & 0.08 & 0.62 & 1.08 & 0.06 & 11 & 2.29 \\
\hline & Bt1 & 5.96 & 4.34 & 7.74 & 0.09 & 0.29 & 0.50 & 0.03 & 10 & 1.42 \\
\hline & $\mathrm{Bt} 2$ & 6.26 & 4.52 & 7.71 & 0.06 & 0.12 & 0.22 & 0.01 & 9 & 1.58 \\
\hline & $\mathrm{Bt} 3$ & 5.46 & 4.50 & 7.74 & 0.06 & 0.50 & 0.87 & 0.04 & 12 & 1.04 \\
\hline \multirow[t]{4}{*}{ Uyole } & Ap & 6.78 & 5.02 & 7.82 & 0.07 & 1.52 & 2.64 & 0.11 & 14 & 11.17 \\
\hline & $\mathrm{BA}$ & 7.20 & 5.00 & 7.76 & 0.09 & 0.89 & 1.54 & 0.06 & 16 & 1.37 \\
\hline & $\mathrm{CB}$ & 7.02 & 5.12 & 7.93 & 0.08 & 0.34 & 0.22 & 0.02 & 6 & 1.46 \\
\hline & $2 \mathrm{Bt}$ & 7.40 & 4.92 & 7.99 & 0.09 & 0.13 & 0.59 & 0.02 & 16 & 1.54 \\
\hline
\end{tabular}




\subsubsection{Organic Carbon and Organic Matter Contents}

Uyole showed medium to high organic carbon and organic matter contents for the A horizon [23]. The organic carbon was observed to be $1.52 \%$ and the respective organic matter was $2.64 \%$. Seatondale had low organic carbon content, the observed values being $0.65 \%$ OC and $1.12 \%$ OM. The soils have been rated as having very low to low organic carbon. In case of B horizons, Seatondale had high organic carbon and organic matter values, $0.99 \%$ and $1.72 \%$, respectively (Table $6)$. However, Inyala and Uyole had very low to low organic carbon and organic matter contents with values $0.12 \%$ and $0.22 \%$, respectively. Generally, the trends indicate that the OC is decreasing with an increasing depth; in topsoils higher values are observed than in the subsoils; probably this is attributed to accumulation of plant residues on the topsoils [21]. These results provide the same trend as the results of a study on volcanic soils of some districts of Mbeya region, Tanzania [23, 24].

\subsubsection{Total Nitrogen and $C: N$ Ratios}

Amongst the study soils, the A horizon of Mbimba pedon was observed to contain low nitrogen content while that of Seatondale contains very low total nitrogen valued $0.12 \%$ and $0.06 \%$, respectively. In case of B horizons, the Uyole, Inyala and Seatondale pedons contain very low nitrogen (Table 6). The results show that, the study soils will require nitrogen replenishment in order to improve corn productivity of such soil. The $\mathrm{C}: \mathrm{N}$ ratios of the A horizons classify the soils to have good to moderate quality in terms of nitrogen mineralization [24]. According to [21], C:N ratio of 10:1 is an indicator of good quality of organic material. However, it has been shown that $\mathrm{C}: \mathrm{N}$ ratio might not be a good indicator of soil fertility; therefore it is better to use individual $\mathrm{C}$ and $\mathrm{N}$ values.

\subsubsection{Available Phosphorus}

The phosphorus levels for the study soils indicate that the A horizon's available phosphorus is medium at Inyala, Seatondale, Uyole and low at Mbimba, with values of 12.90 , $10.67,11.17$ and $5.17 \mathrm{mg} / \mathrm{kg}$, respectively (Table 6) [24]. The B horizon's values were rated low with values $<6 \mathrm{mg} / \mathrm{kg}$ at Mbimba. The critical level for available $\mathrm{P}$ falls between 7-15 $\mathrm{mg} / \mathrm{kg}$ below which $\mathrm{P}$ deficiency symptoms are likely to be manifested amongst many crops [21]. Soils' low available phosphorus was associated with the low $\mathrm{pH}$ values responsible for aluminium toxicity condition where phosphorus is locked in complex aluminium compounds, the result of which being rendering phosphorus not readily available for plant uptake. Phosphorus fixation is common for soils with $\mathrm{pH} \leq 5.5$; it is driven by the oxides and hydroxides of iron, aluminium and manganese [24].

\subsubsection{Cation Exchange Capacity}

CEC of the surface A horizon ranged between medium and high (Table 7). Mbimba and Seatondale were observed to have high CEC, Inyala and Uyole medium CEC. The four values are $36.4,17.2,19.6$ and $22.8 \mathrm{cmol}_{(+)} / \mathrm{kg}$ respectively. The $\mathrm{B}$ horizon also had medium to high $\mathrm{CEC}$ values. There is association between particle size distribution and $\mathrm{CEC}$ values of the study soils among sites. Seatondale showed lower CEC values than Mbimba [24]. Literature indicates that; CEC provides a buffering effect to change in $\mathrm{pH}$, availability of nutrients and levels of $\mathrm{Ca}$ in the soils; it also controls and stabilizes soil structure and nutrients' availability for optimal plant growth and development $[21,24]$.

Table 7. Exchangeable cations and related chemical properties of representative pedons of the SHZT.

\begin{tabular}{|c|c|c|c|c|c|c|c|}
\hline \multirow{2}{*}{ Pedon Id } & \multirow{2}{*}{ Horizon } & \multicolumn{4}{|c|}{ Exchangeable bases $\mathrm{cmol}_{(+)} / \mathbf{k g}$} & \multirow{2}{*}{ CEC $\mathrm{cmol}_{(+)} / \mathrm{kg}$} & \multirow{2}{*}{$\% \mathrm{BS}$} \\
\hline & & $\mathbf{C a}$ & Mg & $\mathbf{K}$ & $\mathbf{N a}$ & & \\
\hline \multirow[t]{6}{*}{ Seatondale } & Ap & 4.01 & 0.66 & 0.61 & 0.08 & 17.20 & 31.2 \\
\hline & $\mathrm{AB}$ & 3.46 & 0.50 & 0.19 & 0.07 & 20.80 & 20.3 \\
\hline & Bt1 & 8.47 & 1.56 & 0.37 & 0.09 & 16.00 & 65.6 \\
\hline & Bt2 & 6.80 & 2.02 & 0.48 & 0.11 & 18.40 & 51.2 \\
\hline & Bt3 & 6.80 & 1.87 & 0.99 & 0.06 & 20.60 & 47.1 \\
\hline & Bt4 & 4.57 & 1.67 & 0.99 & 0.29 & 28.60 & 26.3 \\
\hline \multirow[t]{5}{*}{ Mbimba } & Ap & 7.36 & 1.87 & 2.03 & 0.07 & 36.40 & 31.1 \\
\hline & $\mathrm{BA}$ & 10.14 & 1.39 & 2.41 & 0.16 & 33.00 & 42.7 \\
\hline & Bt1 & 6.80 & 3.86 & 6.09 & 0.27 & 31.40 & 54.2 \\
\hline & Bt2 & 6.24 & 2.49 & 7.30 & 0.28 & 21.60 & 75.5 \\
\hline & Bt3 & 6.24 & 3.23 & 8.12 & 0.32 & 26.00 & 68.9 \\
\hline \multirow[t]{5}{*}{ Inyala } & $\mathrm{Ap}$ & 12.93 & 3.41 & 1.14 & 0.11 & 19.60 & 89.7 \\
\hline & BA & 11.26 & 2.55 & 0.71 & 0.20 & 18.40 & 80.0 \\
\hline & Bt1 & 9.03 & 2.46 & 1.50 & 0.42 & 22.00 & 61.0 \\
\hline & Bt2 & 6.24 & 2.20 & 1.50 & 0.21 & 23.80 & 42.7 \\
\hline & Bt3 & 8.47 & 2.67 & 1.66 & 0.22 & 20.40 & 63.9 \\
\hline \multirow[t]{4}{*}{ Uyole } & Ap & 16.83 & 3.37 & 0.62 & 0.27 & 22.80 & 92.5 \\
\hline & BA & 12.93 & 2.88 & 5.42 & 0.45 & 24.20 & 89.6 \\
\hline & $\mathrm{CB}$ & 8.47 & 2.67 & 10.83 & 1.41 & 21.60 & 108.3 \\
\hline & $2 \mathrm{Bt}$ & 10.70 & 3.07 & 13.84 & 2.06 & 24.40 & 121.6 \\
\hline
\end{tabular}




\subsubsection{Exchangeable Bases and Base Saturation}

Table 7 shows data on exchangeable bases. Exchangeable $\mathrm{Ca}^{2+}$ content was variable across and within the pedons. Uyole and Inyala showed high exchangeable $\mathrm{Ca}^{2+}$ in the A horizons, while Seatondale and Mbimba showed low and medium exchangeable $\mathrm{Ca}^{2+}$, respectively [24]. The $\mathrm{B}$ horizons had exchangeable $\mathrm{Ca}^{2+}$ values varying from low to high. The least value of all was observed at Seatondale (Table 7). Exchangeable $\mathrm{Ca}^{2+}$ levels were observed to decrease down the profile for Uyole, Mbimba, and Inyala sites, while it increased for Seatondale site. Exchangeable $\mathrm{Mg}^{2+}$ levels had a varying trend across the sites and down the profiles. Exchangeable $\mathrm{Mg}^{2+}$ for $\mathrm{A}$ horizons ranged between $3.41 \mathrm{cmol}_{(+)} / \mathrm{kg}$ and $0.66 \mathrm{cmol}_{(+)} / \mathrm{kg}$, soils of Mbimba and Seatondale showed very low exchangeable $\mathrm{Mg}^{2+}$, those of Inyala and Uyole showed low exchangeable $\mathrm{Mg}^{2+}$, while for the B horizons it ranged between $3.86 \mathrm{cmol}_{(+)} / \mathrm{kg}$ and $0.50 \mathrm{cmol}_{(+)} / \mathrm{kg}$. The B horizons showed relatively more exchangeable $\mathrm{Mg}^{2+}$ compared to the A horizons. It increased down the profile for the soils of Seatondale and Mbimba, and decreased for the soils of Uyole while remaining constant for Inyala (Table 7). The four pedons showed medium to very high exchangeable potassium levels (Table 7). The A-horizon values were $10.83 \mathrm{cmol}_{(+)} / \mathrm{kg}, 2.03 \mathrm{cmol}_{(+)} / \mathrm{kg}, 1.14 \mathrm{cmol}_{(+)} / \mathrm{kg}$ and 0.61 $\mathrm{cmol}_{(+)} \mathrm{kg}$ for Uyole, Mbimba, Inyala, and Seatondale, respectively. The B horizons had values ranging from very low to very high in Seatondale and Uyole with values of 0.19 and $13.84 \mathrm{cmol}_{(+)} / \mathrm{kg}$, respectively. The exchangeable potassium generally showed increasing trend down the pedons in all sites (Table 7). A-horizons of the study areas showed very low to low exchangeable sodium. The observed values were $0.27,0.11$, 0.07 , and $0.08 \mathrm{cmol}_{(+)} / \mathrm{kg}$ for Uyole, Inyala, Mbimba and Seatondale, respectively (Table 7). None of the A horizons was found to be sodic. The B horizons showed very low to very high exchangeable sodium. The deep B horizon in Uyole was found to be slightly sodic and the rest of the B horizons in other sites were non-sodic. The topsoils of Seatondale and Mbimba indicated medium soil fertility status with the BS\% between 20 and 50; whereas Uyole and Inyala indicated high fertility status with values $>50$. The literature indicates that high fertility soils have base saturation greater than $50[24,28,29]$.

Table 8. Nutrient ratios for the representative soils of the SHZT.

\begin{tabular}{|c|c|c|c|c|c|}
\hline Pedon Id & Horizon & $\mathrm{Ca} / \mathrm{TEB}$ & $\mathrm{Ca} / \mathrm{Mg}$ & K / Mg & K/CEC (\%) \\
\hline \multirow[t]{6}{*}{ Seatondale } & $\mathrm{Ap}$ & 0.75 & 6.07 & 0.92 & 3.55 \\
\hline & $\mathrm{AB}$ & 0.82 & 6.87 & 0.37 & 0.90 \\
\hline & Bt1 & 0.81 & 5.43 & 0.23 & 2.29 \\
\hline & Bt2 & 0.72 & 3.36 & 0.24 & 2.61 \\
\hline & Bt3 & 0.70 & 3.65 & 0.53 & 4.79 \\
\hline & Bt4 & 0.61 & 2.74 & 0.59 & 3.45 \\
\hline \multirow[t]{5}{*}{ Mbimba } & Ap & 0.65 & 3.94 & 1.09 & 5.58 \\
\hline & BA & 0.72 & 7.30 & 1.73 & 7.29 \\
\hline & Bt1 & 0.40 & 1.76 & 1.58 & 19.40 \\
\hline & Bt2 & 0.38 & 2.51 & 2.93 & 33.78 \\
\hline & Bt3 & 0.35 & 1.93 & 2.52 & 31.24 \\
\hline \multirow[t]{5}{*}{ Inyala } & Ap & 0.74 & 3.79 & 0.33 & 5.80 \\
\hline & BA & 0.76 & 4.41 & 0.28 & 3.88 \\
\hline & Bt1 & 0.67 & 3.67 & 0.61 & 6.84 \\
\hline & Bt2 & 0.61 & 2.84 & 0.69 & 6.32 \\
\hline & $\mathrm{Bt} 3$ & 0.65 & 3.17 & 0.62 & 8.16 \\
\hline \multirow[t]{4}{*}{ Uyole } & Ap & 0.80 & 4.99 & 0.18 & 2.72 \\
\hline & BA & 0.60 & 4.48 & 1.88 & 22.38 \\
\hline & $\mathrm{CB}$ & 0.36 & 3.17 & 4.05 & 50.14 \\
\hline & $2 \mathrm{Bt}$ & 0.36 & 3.49 & 4.51 & 56.72 \\
\hline
\end{tabular}

\subsubsection{Nutrient Ratios}

The availability of plant nutrients does not only depend on absolute concentrations of nutrients but on nutrient balance as well. Thus the uptake of nutrient by crops is influenced by the relative concentrations of exchangeable bases [21]. The $\mathrm{Ca} / \mathrm{Mg}$ ratios in the study soils were above the optimal levels for Uyole, Inyala and Mbimba (Table 8). Availability of $\mathrm{Mg}$ and $\mathrm{P}$ is reduced if the $\mathrm{Ca} / \mathrm{Mg}$ ratios exceed $5: 1$. The epipedons indicated ratios ranging from 3.75 to 7.30 . The $\mathrm{Ca} / \mathrm{Mg}$ ratios below 5:1 are considered favourable for most crops $[21,23]$. The epipedons' $\mathrm{K} / \mathrm{Mg}$ ratios ranged from 0.18 to 1.88 (Table 8 ). It is recommended that $\mathrm{K} / \mathrm{Mg}$ should be less than 1.5 for the uptake of $\mathrm{Mg}^{2+}$ from soil by plants [26]. The epipedons' $\mathrm{K} / \mathrm{CEC}$ is greater than $2 \%$ for all study pedons in SHZT. This implies favorable conditions for production of tropical crops [23, 29, 30].

Table 9. Summary of diagnostic horizons and other features of representative pedons of the SHZT

\begin{tabular}{|c|c|c|c|c|c|}
\hline \multicolumn{3}{|c|}{ USDA Soil Taxonomy system [31] } & \multicolumn{3}{|c|}{ World Reference Base for Soil Resources [32] } \\
\hline Pedon Id & $\begin{array}{l}\text { Diagnostic } \\
\text { epipedon and/or } \\
\text { subsurface horizon }\end{array}$ & Other diagnostic features & $\begin{array}{l}\text { Diagnostic horizons, } \\
\text { properties and } \\
\text { materials }\end{array}$ & Prefix qualifiers & Suffix qualifiers \\
\hline Seatondale & $\begin{array}{l}\text { Ochric epipedon; } \\
\text { Argillic horizon }\end{array}$ & $\begin{array}{l}\text { Deep; loamy; slightly to moderately acid; } \\
\text { udic SMR; isothermic STR; presence of } \\
\text { clay cutans }\end{array}$ & Argic horizon & Cutanic, Haplic & Siltic, Chromic \\
\hline Mbimba & $\begin{array}{l}\text { Ochric epipedon; } \\
\text { Argillic horizon }\end{array}$ & $\begin{array}{l}\text { Very deep; clayey; slightly to moderately } \\
\text { acid; udic SMR, isothermic STR, presence } \\
\text { of clay skins }\end{array}$ & Argic horizon & Cutanic, Haplic & $\begin{array}{l}\text { Manganiferric, } \\
\text { Epidystric, Profondic, } \\
\text { Clayic }\end{array}$ \\
\hline Inyala & $\begin{array}{l}\text { Mollic epipedon; } \\
\text { Argillic horizon }\end{array}$ & $\begin{array}{l}\text { Very deep; clayey; slightly to moderately } \\
\text { acid; udic SMR; isothermic STR; presence } \\
\text { of clay skins }\end{array}$ & $\begin{array}{l}\text { Mollic horizon; argic } \\
\text { horizon }\end{array}$ & Cutanic, Haplic & $\begin{array}{l}\text { Manganiferric, } \\
\text { Profondic, Clayic }\end{array}$ \\
\hline Uyole & Mollic epipedon & $\begin{array}{l}\text { Very deep; loamy; neutral to mildly } \\
\text { alkaline, udic SMR; isothermic STR; } \\
\text { presence of volcanic materials (mainly } \\
\text { pumice and ash) }\end{array}$ & $\begin{array}{l}\text { Mollic horizon; } \\
\text { vitric/tephric } \\
\text { materials }\end{array}$ & Vitric, Haplic & Tephric, Siltic \\
\hline
\end{tabular}




\subsection{Classification of the Studied Pedons}

Soil morphology and physico-chemical data were used to define diagnostic horizons and other features used for soil classification. Ochric and mollic horizons were the main diagnostic epipedons while argillic horizon was the diagnostic B horizon common in all the pedons (Table 9). According to USDA Soil Taxonomy [31], the soils have been classified as Fine, illitic, active, isothermic Typic Hapludult; Fine, illitic, active, isothermic Andic Paleudalf; Fine, illitic, active, isothermic Mollic Paleudalf; and Pumiceous, mixed, superactive, isothermic Typic Hapludand. The corresponding equivalent FAO-WRB [32] Tier-2 taxa are Haplic Cutanic Luvisol (Siltic, Chromic); Haplic Cutanic Luvisol (Manganiferric, Epidystric; Profondic, Clayic); Haplic Cutanic Luvisol (Manganiferric, Profondic, Clayic); and Haplic Vitric Paeozem (Tephric, Siltic), respectively for Seatondale, Mbimba, Inyala and Uyole (Table 10).

Table 10. Classification of the representative pedons of SHZT.

\begin{tabular}{|c|c|c|c|c|c|c|}
\hline \multicolumn{6}{|c|}{ USDA Soil Taxonomy classification system [31] } & \multirow{2}{*}{ World Reference Base for Soil Resources[32] } \\
\hline Pedon Id & Order & Suborder & Greatgroup & Subgroup & Family & \\
\hline Seatondale & Ultisol & Udult & Hapludult & $\begin{array}{l}\text { Typic } \\
\text { Hapludult }\end{array}$ & $\begin{array}{l}\text { Fine, Illitic, Active, } \\
\text { Isothermic, Typic Hapludult }\end{array}$ & Haplic Cutanic Luvisol (Siltic, Chromic) \\
\hline Mbimba & Alfisol & Udalf & Paleudalf & $\begin{array}{l}\text { Andic } \\
\text { Paleudalf }\end{array}$ & $\begin{array}{l}\text { Fine, Illitic, Active, } \\
\text { Isothermic, Andic Paleudalf }\end{array}$ & $\begin{array}{l}\text { Haplic Cutanic Luvisol (Manganiferric, Epidystric, } \\
\text { Profondic Clayic) }\end{array}$ \\
\hline Inyala & Alfisol & Udalf & Paleudalf & $\begin{array}{l}\text { Mollic } \\
\text { Paleudalf }\end{array}$ & $\begin{array}{l}\text { Fine, Illitic, Active, } \\
\text { Isothermic, Mollic Paleudalf }\end{array}$ & $\begin{array}{l}\text { Haplic Cutanic Luvisol (Manganiferric, Profondic, } \\
\text { Clayic) }\end{array}$ \\
\hline
\end{tabular}

\subsection{Pedogenesis in the Study Area}

Among the noticeable predominant pedogenic processes observed in this study include humification, translocation and eluviation/illuviation. The study area has been affected by the anthropogenic activities such as field operations using both simple and heavy farm implements. The enrichment of organic and mineral materials has been observed in all pedons. The dark colors and high percent of organic carbon in the epipedons are good indicators of humification as pedogenic process taking place within and across the pedons (Tables 3 and 6). The translocation of the materials is indicated by the empirical evidence of high \% clay in the B horizons especially at Seatondale, Mbimba and Inyala. The eluviation/illuviation as pedogenic processes manifest the translocation of clay material from the epipedons to $\mathrm{B}$ horizons (Table 5). These findings are in line with similar works elsewhere [30, 33, 34, 35, 36].

\section{Conclusion}

The four sites are highly variable in terms of texture, $\mathrm{pH}$ and $\%$ base saturation. However, they share many characteristics such as being well drained, having reddish B horizons, subangular blocky structures, the epipedons being friable and $\mathrm{B}$ horizons haing firm consistence. The predominant pedogenic processes in the SHZT are humification, translocation, eluviation and illuviation. The soils of the study areas are deep to very deep suitable for production of both shallow and long rooted crops. Based on the examination of the chemical properties; $\mathrm{pH}, \mathrm{CEC}, \mathrm{BS}$, SOM and nutrient balance, the three pedons namely Uyole, Mbimba and Inyala are considered inherently fertile and classified as Alfisols and Andisols, whereas Seatondale pedon has depleted fertility and classified as Ultisols. In addition, $\mathrm{C}: \mathrm{N}$ were consistently $<20: 1$, indicating that these soils are capable of mineralizing the organic nitrogen and availing it for plant uptake. Nitrogen and phosphorus are the most limiting nutrients for crop production in the study area; therefore the use of $\mathrm{N}$ and $\mathrm{P}$ fertilizers will enhance crop production in the area.

\section{References}

[1] Brekke, K. A., Iversen, V. and Aune, J. B. (1999). Tanzania's soil wealth. Environment and Development Economics 4: 333-356.

[2] United Republic of Tanzania (2006). National adaptation programme of action.

https://www.google.co.tz/?gfe_rd=cr\&ei=lmU4VobwGITL0w Wh76UY\#q=national + adaptation + programme + of + action $+\tan$ zania (Retrieved August 12, 2015).

[3] Msanya, B. M., Magoggo, J. P. and Otsuka, H. (2002). Development of soil surveys in Tanzania. Pedologist 46:7988 .

[4] Szilas, C., Møberg, J. P., Borggaard, O. K. and Semoka J. M. (2005). Mineralogy of characteristic well-drained soils of subhumid to humid Tanzania. Acta Agriculturae Scandinavica, Section B- Soil and Plant Science 55: 241-251.

[5] Survey and Mapping Division (1983). Ministry of Lands, Housing and Urban Development. Topographic map of Iringa. Scale of 1:50 000. Sheet 215/3. Dar es Salaam, Tanzania.

[6] Geological Survey Department (1962). Geological map of Iringa, at scale 1:125:000, QDS 215. Geological Survey of Tanganyika. Dodoma, Tanzania.

[7] Schoeneberger, P. J., Wysocki, D. A., Benham, E. C. and Soil Survey Staff (2012). Field book of describing and sampling soils, Version 3.0. Natural Resources Conservation Service, National Soil Survey Center, Lincoln, NE. 
[8] Soil Survey Staff (1999). Soil Taxonomy. A Basic System of Soil Classification for Making and Interpreting Soil Surveys. Agricultural Handbook 436, Natural Resources Conservation Service, USDA, Washington DC, USA, 869 pp.

[9] Black, G. R. and Hartge, K. H. (1986). Bulk density. In: A. Klute (Ed.). Methods of soil analysis, Part $1\left(^{\text {nd }} E d\right)$. Agronomy Monograph No. 9. American Society of Agronomy and Soil Science Society of America, Madison, WI. pp. 364376.

[10] National Soil Service (1990). Laboratory procedures for routine analysis, $3^{\text {rd }}$ edition. Agricultural Research Institue. Mlingano Tanga, Tanzania. $212 \mathrm{pp}$.

[11] Mclean, E. O. (1986). Soil pH and lime requirement. In: L. A. Page, R. H. Miller, and D. R. Keeney (Eds.) Methods of soil analysis, Part 2 ( $2^{\text {nd }}$ Ed.) Agronomy Monograph No. 9. American Society of Agronomy and Soil Science Society of America, Madison, WI. p. 199-223.

[12] Fieldes, M. and Perrot, K. W. (1966). The nature of allophane in soils. I. Significance of randomness in pedogenesis. New Zealand Journal of Science 9:622-632.

[13] Nelson, D. W. and Sommers, L. E. (1982). Total organic carbon. In: L. A. Page, R. H. Miller, and D. R. Keeney (Eds.) Methods of soil analysis, Part 2 ( $2^{\text {nd }}$ Ed.) Agronomy Monograph No. 9. American Society of Agronomy and Soil Science Society of America, Madison, WI. pp. 539-579.

[14] Duursma, E. K. and Dawson, R. (1981). Marine organic chemistry: Evolution, composition, interactions, and chemistry of organic matter in seawater. Elsevier, New York. $521 \mathrm{pp}$.

[15] Bremmer, J. M and Mulvaney, C. S. (1982). Total nitrogen. In: L. A. Page, R. H. Miller, and D. R. Keeney (Eds.) Methods of soil analysis, Part 2 ( $2^{\text {nd }}$ Ed.) Agronomy Monograph No. 9. American Society of Agronomy and Soil Science Society of America, Madison, WI. pp. 595-624.

[16] Bray, R. H. and Kurtz, L. T. (1945). Determination of total, organic and available forms of phosphorus in soil. Soil Science 58: 39-45.

[17] Murphy, J. and Riley, J. P. (1962). A modified single solution method for the determination of phosphate in natural waters. Analytica Chimica Acta 27:31-36.

[18] Watanabe, F. S. and Olsen, S. R. (1965). Test of an ascorbic acid method for determining phosphorus in Central Illinois: Midwest Friends of the Pleistocene 26th Field Conf., Campaign, IL, Illinois Geol. Surv. Guidebook 13:129-134.

[19] Chapman, H. D. 1965. Cation Exchange Capacity. In: C. A. Black (Ed.) Methods of soil analysis. Agronomy Monograph No. 9. American Society of Agronomy and Soil Science Society of America, Madison, WI.891. 901 pp.

[20] Thomas, G. W. (1982). Exchangeable cations. In: L. A. Page, R. H. Miller, and D. R. Keeney (Eds.) Methods of soil analysis, Part 2 ( $2^{\text {nd }}$ Ed.) Agronomy Monograph No. 9. American Society of Agronomy and Soil Science Society of America, Madison, WI. pp 595-624.

[21] Mbaga, H. R., Msanya, B. M. and Mrema, J. P. (2017). Pedological characterization of typical soil of Dakawa Irrigation Scheme, Mvomero District, Morogoro Region, Tanzania. International Journal of Current Research Biosciences and Plant Biology 4 (6):77-86.
[22] Moberg, J. P. (2000). Soil and plant analysis manual. The Royal Veterinary and Agricultural University Chemistry Department, Copenhagen, Denmark. 133 pp.

[23] Landon, J. R. (1991). Booker tropical soil manual. A handbook for soil survey and agricultural land evaluation in Tropics and Subtropics. John Wiley, New York. 474 pp.

[24] Msanya, B. M., Otsuka, H., Araki, S. and Fujitake, N. (2007). Characterization of volcanic ash soils in southwestern Tanzania: Morphology, physicochemical properties, and classification. African Study Monographs, Suppl. 34: 39-55.

[25] Berryman, C. and Eavis, B. (1984). CH. 6, Soil physics. P.58105. In: J. R. London (Ed). Booker Tropical Soil Manual. Booker Agric. Intl. Ltd., London.

[26] Young, A. (1976). Tropical soils and soil survey. Cambridge University Press. Cambridge. 468 pp.

[27] Baize, D. 1993. Soil science analysis. John Wiley and Sons, New York. 192 pp.

[28] Kalala, A. M., Msanya, B. M., Amuri, N. A. and Semoka, J. M. (2017). Pedological characterization of some typical alluvial soils of Kilombero District, Tanzania. American Journal of Agriculture and Forestry 5 (1):1-11.

[29] Massawe, I. K., Msanya, B. M. and Rwehumbiza, F. B. (2017). Pedological characterization and fertility evaluation of paddy soils of Mvumi village, Kilosa District, Tanzania. International Journal of Current Research Biosciences and Plant Biology 4 (4):49-60.

[30] Uwingabire, S., Msanya, B. M., Mtakwa, P. W., Uwitonze, P. and Sirikare, S. N. (2016). Pedological characterization of soils developed on gneissic - Granites in the Congo Nile watershed divide and central plateau zones, Rwanda. International Journal of Current Research 8 (09):3948939501.

[31] Soil Survey Staff (2014). Keys to Soil Taxonomy. $12^{\text {th }}$ Edition. United States Department of Agriculture, Natural Resources Conservation Service. 360 pp.

[32] World Reference Base for Soil Resources (2006). First update 2007. FAO: Rome Available at: www. fao. org.

[33] Karuma, A. N., Gachene, C., Msanya, B. M., Mtakwa, P. W., Amuri, N. and Gicheru, P. T. (2014). Soil morphology, physico-chemical properties and classification of typical soils of Mwala District, Kenya. International Journal of Plant \& Soil Science 4 (2): 156 - 170.

[34] Uwitonze, P., Msanya, B. M., Mtakwa, P. W., Uwingabire, S. and Sirikare, S. (2016). Pedological characterization of soils developed from volcanic parent materials of Northern Province of Rwanda. Agriculture, Forestry and Fisheries 5 (6):225-236.

[35] Kebeney, S. J., Msanya, B. M., Ng'etich, W. K., Semoka, J. M. and Serrem, C. K. (2014). Pedological characterization of some typical soils of Busia County, Western Kenya: Soil morphology, physico-chemical properties, classification and fertility trends. International Journal of Plant \& Soil Science 4 (1): $29-44$.

[36] Tenga, J. J., Msanya, B. M., Semoka, J. M., Semu, E. and Mwango, S. B. (2018). Pedological Characterization and Classification of Some Typical Soils in Three Agro-Ecological Settings of South-Eastern Tanzania. International Journal of Scientific \& Engineering Research 9 (2):692 - 702. 